\title{
Article 4. Relationship with International Agreements and Instruments
}

1. The provisions of this Protocol shall not affect the rights and obligations of any Party deriving from any existing international agreement, except where the exercise of those rights and obligations would cause a serious damage or threat to biological diversity. This paragraph is not intended to create a hierarchy between this Protocol and other international instruments.

2. Nothing in this Protocol shall prevent the Parties from developing and implementing other relevant international agreements, including other specialized access and benefit-sharing agreements, provided that they are supportive of and do not run counter to the objectives of the Convention and this Protocol.

3. This Protocol shall be implemented in a mutually supportive manner with other international instruments relevant to this Protocol. Due regard should be paid to useful and relevant ongoing work or practices under such international instruments and relevant international organizations, provided that they are supportive of and do not run counter to the objectives of the Convention and this Protocol.

4. This Protocol is the instrument for the implementation of the access and benefit-sharing provisions of the Convention. Where a specialized international access and benefit-sharing instrument applies that is consistent with, and does not run counter to the objectives of the Convention and this Protocol, this Protocol does not apply for the Party or Parties to the specialized instrument in respect of the specific genetic resource covered by and for the purpose of the specialized instrument.

\section{Overview}

Article 4 is a complex provision seeking to clarify the relationship of the Protocol with existing and future international agreements. ${ }^{1}$ First, it encapsu-

1 From a political science perspective, this has been seen as 'an attempt to reinforce the central position of the international biodiversity regime in global ABS governance' by seeking 
lates the implied compromise reached by СвD Parties that the Nagoya Protocol will not serve as a comprehensive framework, ${ }^{2}$ in the global governance of ABS transactions. As it will be argued below, it indicates (although not very clearly) that the Protocol will address ABs issues when and to the extent to which these are not addressed by other international ABS instruments. It will not subsume previous ABS agreements or subordinate to the Protocol rules future ABS agreements. ${ }^{3}$ Vis-à-vis these instruments, the Protocol thus establishes a residual regime.

Nonetheless, this provision aims to limit the discretion of Protocol Parties in negotiating new international instruments, by reference to mutual supportiveness with the objective of the $\mathrm{CBD}$ and the Protocol. ${ }^{4}$ In that connection, it is significant that the question of the relationship of the Protocol with other international instruments is addressed in the operative part of the Protocol, rather than in its preamble. This placement would make Article 4 a 'substantive standard of conduct incumbent upon State Parties,' rather than just an aid to contextual interpretation. ${ }^{5}$ The provision's convoluted language, however, complicates interpretation and may well prevent the Article from realizing

to clarify the division of labour among different international processes and providing guidance for future developments in other institutions, and has been considered to have had some success in that direction (in the context of the General Assembly Working Group on Marine Biodiversity, the Antarctic Treaty System, the World Health Organization (wHo) and WIPO): Oberthür and Pozarowska, "Impact of the Nagoya Protocol," op. cit., 179, 187-189, 231, 240 and 243.

2 Note the proposed preambular language that did not make it into the final text of the Protocol 'noting that this Protocol will be the comprehensive protocol on access and benefit-sharing and that WIPO should use this Protocol as a basis for its ongoing work', emphasis added, СвD Working Group on ABs, "Report of the third part of the ninth meeting of the Ad Hoc Openended Working Group on Access and Benefit-Sharing" (17 October 2010) Un Doc UNEP/CBD/ COP/10/5/Add.5, 8 .

3 This is also reflected in the CBD COP decision adopting the final text of the Nagoya Protocol (свD Decision 10/1, 6th preambular recital, where свD Parties recognized 'that the International Regime is constituted of the Convention on Biological Diversity, the Nagoya Protocol..., as well as complementary instruments, including the International Treaty on Plant Genetic Resources for Food and Agriculture and the Bonn Guidelines..., emphasis added).

4 The role of the Protocol as a regime that applies by default (when and to the extent to which other international ABS instruments do not apply) also explains the provisions on 'special considerations' in Article 8. See this commentary on Article 8.

5 Riccardo Pavoni, "Mutual Supportiveness as a Principle of Interpretation and Law-Making: A Watershed for the 'wTO-and-Competing-Regimes' Debate?," European Journal of International Law 21 (2010): 649, 658. 
its aim. Article 4 in part combines language from the $\mathrm{CBD},{ }^{6}$ with language on mutual supportiveness that was borrowed (in a slightly different formulation) from other multilateral environmental agreements. ${ }^{7}$

The sections below aim to suggest a coherent and effective interpretation of this Article by differentiating between its bearing on the relationship between the Protocol and other existing agreements, future international agreements, and more specifically other (existing and future) international agreements or instruments specialized in ABS. The negotiating history is particularly significant to understand which existing and future international instruments were identified by the Protocol negotiators as directly relevant for the interpretation or implementation of the Nagoya Protocol. ${ }^{8}$

Relationship with Existing Agreements

Article 4(1) focuses on the relationship of the Protocol with existing international agreements. The provision attempts to clarify the relationship between the Protocol and other international treaties (not necessarily environmental ones) ${ }^{9}$ in existence at the time of its adoption (or possibly at the time of its entry into force). In doing so, Article 4 relies on the text of Св D Article 22(1) verbatim. ${ }^{10}$ Furthermore, it adds that the provision is 'not intended to create a hierarchy between this Protocol and other international instruments'.11

6 СвD Article 22(1), which reads 'The provisions of this Convention shall not affect the rights and obligations of any Contracting Party deriving from any existing international agreement, except where the exercise of those rights and obligations would cause a serious damage or threat to biological diversity. This accords with VCLT Article 30(2), which reads: 'When a treaty specifies that is subject to, or that it is not to be considered incompatible with, an earlier or later treaty, the provisions of that other treaty prevail.'

Pavoni, "Mutual Supportiveness," op. cit., 205-206.

8 See СвD Working Group on ABs, "Study on the relationship between an international regime on access and benefit-sharing and other international instruments and forums that govern the use of genetic resources" (3 March 2009) UN Doc UNEP/CBd/WG-ABs/7/ INF/3/Part.1.

9 Glowka, Burhenne-Guilmin and Synge, Guide to the Convention on Biological Diversity, op. cit., 109.

10 See fn. 6 above.

11 The same language can be found in the preamble of the Rotterdam Convention on the Prior Informed Consent Procedure for Certain Hazardous Chemicals and Pesticides in International Trade (Rotterdam, 10 September 1998, in force 24 February 2004) 2244 UnTs 337 ('Rotterdam PIC Convention') and Itpgrfa. Note that instead the Cartagena Protocol preamble refers to "not [being] intended to subordinate this Protocol to 
The overall meaning of Article 4(1) is, however, quite unclear. The wording borrowed from the $\mathrm{CBD}$ is that of a reverse conflict clause. It has been interpreted as giving 'conditional priority' to СвD Parties' obligations arising from other treaties existing at the time of the conclusion of the СвD over their obligations arising from the Convention, but only in the absence of a 'serious damage or threat' to biodiversity. ${ }^{12}$ In the presence of such damage or threat, conversely, the СвD would oblige its Parties to give their obligations under the Convention precedence over their obligations from other international agreements. But the Protocol Article 4(1) then adds that the reverse conflict clause is not intended to create a hierarchy among international instruments. The additional wording presumably limits to a case-by-case application the conditional priority assigned to the Protocol by the beginning of Article 4(1). Since priority - rather than 'hierarchical' superiority - should be assigned to other international agreements, in the absence of a serious damage or threat to biodiversity, Article 4(1) expresses the intention to preclude an interpretation of the Protocol that would lead to a modification of Protocol Parties' obligations under other existing international agreements ${ }^{13}$ relevant for ABs.

In doing so, Article 4(1) seems to reflect the wide margin of discretion also afforded by the СвD reverse conflict clause to СвD Parties. It equally implies a duty for Parties (collectively) to be constantly alert to, and promptly identify, any 'serious damage or threat' to biodiversity that may materialize from other international regimes. ${ }^{14}$ In that connection, the normative activity of the СВD governing body is highly significant in periodically crystallizing consensus in the identification of serious threats to biodiversity, thereby triggering the prevalence of the СвD over other obligations arising from existing international agreements..$^{15} \mathrm{~A}$ similar approach in the context of the Nagoya Protocol could thus be adopted, although it is difficult to identify in abstracto specific

other international agreements' (emphasis added) and discussion by Pavoni, "Mutual Supportiveness," op. cit., 654. Note also proposals to include language on non-subordination in the Protocol that were not included in the final text: СвD Working Group on ABS, "Report of the first part of the ninth meeting," UNEP/CBD/WG-ABs/9/3, 108 and ENB 9/527, "Summary of the Resumed Ninth Meeting of the Working Group on ABs," 4.

12 Pavoni, "Mutual Supportiveness," op. cit., 655.

13 Similarly to what was suggested in interpreting comparable language in the Biosafety Protocol by Ruth Mackenzie et al., An Explanatory Guide to the Cartagena Protocol on Biosafety (Gland: IUCN, 2003), 29.

14 Based on a similar interpretation of свD Article 22, see discussion in Elisa Morgera, "Faraway, So Close: A Legal Analysis of the Increasing Interactions between the Convention on Biological Diversity and Climate Change Law," Climate Law 2 (2011): 85, 88.

15 Ibid., 91. 
ABS-related activities that could cause a serious damage or threat to biodiversity. Ultimately, the most effective interpretation of Article 4(1) is thus that Parties should avoid any 'principled' or a priori approach in assessing and addressing the relationship of the Nagoya Protocol with other existing international agreements, but rather focus on a pragmatic, case-by-case approach to mutual supportiveness - as confirmed by the first sentence in Article 4(3).

The concept of 'mutual supportiveness' - that is key to the whole of Article 4 - has a two-fold implication for the conduct of States. ${ }^{16}$ First, it requires, at the interpretative level, that States 'disqualify' solutions to tensions between competing regimes involving the subordination of one regime to the other. Second, at the law-making level, it requires that States exert good-faith efforts to negotiate and conclude instruments that clarify the relationship between competing regimes, particularly when interpretative reconciliation efforts have been exhausted. ${ }^{17}$ Article $4(1)$ thus seems to relate to the first dimension of mutual supportiveness. This is further clarified by the Protocol preamble, where Parties 'recogniz $[e]$ that international instruments related to [ABS] should be mutually supportive with a view to achieving the objectives of the Convention'. 18

In addition, Article 4(3) mandates Parties to implement the Protocol in a mutually supportive manner with other 'relevant' international instruments. It implicitly expects Parties to identify, monitor and take into account international instruments that may not necessarily focus on ABS, but directly or indirectly relate to it. It provides, however, no specific guidance as to how to resolve any conflict that may arise between the Protocol and other international agreements, but rather reflects Parties' 'awareness of the potential for conflict and their aspiration that any such conflict be resolved in a manner that respects both instruments. ${ }^{\prime 19}$

Article 4(3) further encourages ${ }^{20}$ 'due regard ... to useful and relevant ongoing work or practices under such international instruments and relevant international organizations, provided that they are supportive of and do not run counter to the objectives of the Convention and this Protocol' in implementing

\footnotetext{
16 Pavoni, "Mutual Supportiveness," op. cit., 650-651.

17 Ibid., particularly 661-669.

18 Nagoya Protocol 20th preambular recital.

19 As was noted in the context of the Biosafety Protocol: see Mackenzie et al., Explanatory Guide to the Cartagena Protocol, op. cit., 27.

20 Note the non-legally binding language of the second sentence of Nagoya Protocol Article 4(3): 'should.'
} 
the Protocol. The drafting is quite unusual and highly unclear. ${ }^{21}$ The imprecise expression 'ongoing work and practices' ${ }^{22}$ could arguably include not only negotiations of treaties but also of soft-law instruments. It may also refer to negotiations of other (technical) documents or to the conduct of activities on the ground undertaken in the context of international agreements or under the auspices, or with the technical support, of intergovernmental institutions. It remains to be seen which specific 'work and practices' will be deemed 'useful and relevant' to trigger this provision. At the time of the Protocol negotiations, relevant international instrument(s) were being negotiated under the World Health Organization (WHO ${ }^{23}$ and under WIPO, ${ }^{24}$ and relevant discussions were held under the FAO's Commission on Genetic Resources for Food and Agriculture (CGRFA). ${ }^{25}$ As these developments are inherently subject to evolution and other relevant work may be initiated in other intergovernmental contexts, a collective determination of ongoing work and practices for the purposes of Article 4(3) by the Parties may be necessary at regular intervals. The Protocol's governing body is consequently to monitor ongoing intergovernmental ${ }^{26}$ developments on matters related to $\mathrm{ABS}$, as long as they are 'supportive of, and do not run counter to the objectives' of the CBD and the Nagoya Protocol. The Protocol's governing body may then provide consensus guidance in this regard, if necessary, including in the context of its provision on assessment and review. ${ }^{27}$

Singh Nijar "An Asian Developing Country's View," op. cit., 263; Singh Nijar and Pei Fern, Nagoya A Bs Protocol, op. cit., 26; and Greiber et al., Explanatory Guide, op. cit., 78-80.

The expression 'ongoing work in other international forums relating to access and benefitsharing' can also be found in the Nagoya Protocol 18th preambular paragraph, which does not shed further light on the matter.

23 See Marie Wilke, "A Healthy Look at the Nagoya Protocol - Implications for Global Health Governance," in Morgera, Buck and Tsioumani, 2010 Nagoya Protocol on Access and Benefit-Sharing in Perspective, op. cit., 123, 142-143; and section 4.2 below.

24 See section 3.1 below.

25 Chiarolla, Louafi and Schloen, "Analysis of the Relationship", op. cit., 114-115.

26 Ongoing work and practices that involve State and non-State actors, or only non-State actors (i.e., transnational work and practices on ABs as opposed to intergovernmental ones) is not addressed by Nagoya Protocol Article 4(3), since this provision is limited to work or practices 'under [international] instruments and relevant international organizations.' Transnational work and practices may rather be considered as 'codes of conduct, guidelines and best practices and/or standards: see this commentary on Article 20.

See this commentary on Article 31, as СвD Decision 10/1, paragraph 6 suggests with specific regard to the WIPO negotiations. 


\subsection{Examples of Existing Agreements}

While existing international instruments specializing on ABS will be discussed below, at least five sets of existing international norms may be considered relevant for the purposes of Article 4(1) and (3). Parties, in their implementation of the Protocol at the domestic level, as well as in the context of the Protocol's governing body or in other concerned multilateral fora, will have to ensure mutual supportiveness between the Protocol and: i) international law on human rights, ii) the UNESCO Convention on Intangible Cultural Heritage, ${ }^{28}$ iii) the law of the sea, iv) the law of the World Trade Organization (wTO) and v) international investment law.

With regards to international human rights law, the Protocol preamble notes the relevance of the UN Declaration on the Rights of Indigenous Peoples. ${ }^{29}$ While it may be debatable whether, as a formally non-legally binding instrument, UNDRIP may be considered an 'existing international agreement' for the purposes of Article 4, it is certainly true that the Nagoya Protocol will have to be interpreted so as not to derogate from the obligations of Parties under their applicable international human rights agreements, many of which are reflected in UNDRIP. ${ }^{30}$ This relationship may be particularly relevant with regard to indigenous peoples and local communities. ${ }^{31}$ But international human rights law also applies to individuals as users and providers in relation to the notions of participation, access to information and access to justice under the Protocol. ${ }^{32}$ Specific instances where the relationship between the Protocol and international human rights law is particularly relevant will be discussed more specifically in this commentary in relation to the relevant operative provisions of the Protocol. ${ }^{33}$

The scope of the UNESCO Convention on Intangible Cultural Heritage extends to 'knowledge and practices concerning nature', ${ }^{34}$ so also traditional knowledge associated with genetic resources. ${ }^{35}$ To that extent, the UNEsco

28 UNEsco Convention for the Safeguarding of the Intangible Cultural Heritage (Paris, 17 October 2003, in force 20 April 2006) 2368 UnTs 35 (hereinafter, Unesco Convention on Intangible Cultural Heritage).

29 Nagoya Protocol 26th preambular recital.

30 See Introduction to this commentary, section 4.1.

31 On the relevance of indigenous peoples' human rights for local communities, see Introduction to this commentary, section 4.2.

32 Savaresi, "International Human Rights Law Implications," op. cit., 74.

33 See this commentary on Articles 5, 6, 7, 12, 14, 13, 17, 18 and 21.

34 UNEsco Convention on Intangible Cultural Heritage, Article 2(2)(d).

35 Lenzerini, “Indigenous Peoples' Cultural Rights," op. cit., 129. The relevance of the UnESCO Convention for traditional knowledge associated with biodiversity more generally 
Convention appears to qualify as a relevant existing agreement for the purposes of Article 4 of the Protocol. The Convention creates several obligations for its Parties that are of relevance to traditional knowledge associated with genetic resources, such as the obligation to develop inventories of traditional knowledge present in its Parties' territory with the 'participation of communities,'36 and a best-endeavor obligation to adopt domestic measures aimed at 'ensuring access to the intangible cultural heritage while respecting customary practices governing access to specific aspects of such heritage. ${ }^{37}$ Parties both to the Protocol and to the Unesco Convention will thus have to interpret and implement their respective obligations related to traditional knowledge associated with genetic resources in a mutually supportive manner. In particular, Parties to the Nagoya Protocol will have to raise the bar significantly compared to the UNESCO Convention by ensuring PIC (or approval and involvement) is obtained from indigenous and local communities before access to traditional knowledge associated with genetic resources is granted and by ensuring fair and equitable benefit-sharing, in light of the more specific standards included in the Protocol in that regard. ${ }^{38}$

With regard to the law of the sea, ${ }^{39}$ the Protocol will have to be implemented in relation to ABs-related activities in marine areas 'consistently with' the rights and obligations arising from the UN Convention on the Law of the Sea (UNCLOS) or relevant customary law for those Parties to the Protocol that are not Parties to UNCLOS. ${ }^{40}$ In other words, the application of the Nagoya

is currently discussed under the свр Working Group on Article $8(\mathrm{j})$ pursuant to the mandate on misappropriation of traditional knowledge in СвD Decision 11/14, section C, paragraph 2. See свD Article 8(j) Working Group, "How Tasks 7, 10 and 12 could best contribute to work under the Convention and to the Nagoya Protocol. Revised note by the Executive Secretary" (23 September 2013) Un Doc UNEP/CBD/WG8J/8/4/Rev.2, paragraphs 3 and 55; and "Study on How Tasks 7, 10 And 12 of the Revised Programme of Work on Article 8(j) and Related Provisions Could Best Contribute to Work under the Convention and the Nagoya Protocol" (12 September 2013) Un Doc Unep/CbD/WG8J/8/ INF/5, paragraphs 13-14.

36 Unesco Convention on Intangible Cultural Heritage Articles 11(b) and 12(1).

37 Unesco Convention on Intangible Cultural Heritage Article 13(d)(ii), emphasis added. Article 13(d)(iii) also foresees the development of domestic measures aimed at establishing documentation institutions for the intangible cultural heritage and facilitating access to them.

38 We are grateful to Federico Lenzerini for a very useful preliminary exchange of ideas on this question.

39 See свр Working Group on ABs, "Study on the relationship between an international AвS regime, the Antarctic Treaty System and UnCLOS," UNEP/CBD/WG-ABS/7/INF/3/PART3.

While the CвD has 193 Parties, UnCLOs has 166. 
Protocol will have to respect the general jurisdictional framework applicable to the oceans established by the law of the sea, which distinguishes between different areas within and beyond national jurisdiction. In doing so, however, Protocol Parties may face several uncertainties and challenges in implementing the two instruments in a mutually supportive manner, as the law of the sea does not address explicitly questions related to genetic resources. ${ }^{41}$ In areas within national jurisdiction, even when it can be argued that existing provisions under the law of the sea and the Protocol may be interpreted in a mutually supportive way, challenges may arise from the proceduralization and contractualization of ABS transactions required by the Protocol and the UNCLOS consent regime for marine scientific research for commercial purposes, ${ }^{42}$ or from the application of the Protocol provisions concerning indigenous and local communities, on whose rights and traditional knowledge UNCLOS is silent. ${ }^{43}$ Much more uncertainty and controversy surrounds the status and regime applicable to marine genetic resources in areas beyond national jurisdiction, as discussed below. 44

With regard to WTO law, while possible conflicts were very prominent in the negotiations of the Protocol, in particular in relation to IPRs, ${ }^{45}$ the final compromise text carefully avoids any reference to this specific relationship. ${ }^{46}$ In that respect, it has been noted that the Nagoya Protocol was a 'golden opportunity [that] has been lost' for shielding environmental measures taken in the common interest of humanity against essentially reciprocal trade obligations under the Wто. ${ }^{47}$ In fact, it is argued that while the Nagoya Protocol does not impose WтO-inconsistent obligations on its Parties, its neutral ${ }^{48}$ provisions vis-à-vis trade-related measures may allow Parties to pass national ABs legis-

41 An exhaustive analysis of these challenges exceeds the scope of this commentary. A preliminary, but systematic analysis can be found in Salpin, "Law of the Sea", op. cit.

42 Ibid., 161-163.

43 Ibid., 169. Although note that Articles 5(i) and 24(2)(b) of the Agreement for the Implementation of the Provisions of the United Nations Convention on the Law of the Sea of 10 December 1982 relating to the Conservation and Management of Straddling Fish Stocks and Highly Migratory Fish Stocks (New York, 4 August 1995, in force 11 December 2001) 2167 UNTS 3, may be relevant in relation to indigenous peoples and local communities. We are grateful to Adriana Bessa for drawing our attention to this point.

44 See section 4.3 below.

45 See Introduction to this commentary, section 1.1.

46 For this reason, this commentary will address questions related to IPRs only to the extent necessary to better understand the sparse references in the Protocol.

47 Pavoni, "Nagoya Protocol and wTo Law," op. cit., 212.

48 Ibid. 
lation that may be considered at variance with wTO rules and possibly put those Parties on the losing side in a WTo law dispute, because they are unable to justify these measures on the basis of an authoritative mandate from the Protocol. 49

Finally, international investment law may also be relevant. Although there have been no international decisions on a conflict between ABS norms and investment disciplines, it remains a possibility that an investment disputeresolution mechanism may be seized by users who can claim to act as foreign investors against provider-country Parties when domestic ABS provisions implementing the Nagoya Protocol in relation to access ${ }^{50}$ or benefit-sharing 51 may be alleged to conflict with the terms of bilateral investment treaties. ${ }^{52}$ Each Party has thus to ensure that the Nagoya Protocol and applicable investment treaties are implemented in a mutually supportive way. Provider countries may be well advised to explicitly justify domestic ABs frameworks on the basis of the Protocol, as well as of applicable international human rights law in as far as indigenous and local communities are concerned, ${ }^{53}$ to reduce their investment-related litigation risk. ${ }^{4}$ On the other hand, it has been noted that the existence of 'broad permissive commitments' in the Protocol suffices to alert international investors to include risks arising from ABS regulation in their due diligence assessments..$^{55}$

\section{Relationships with Future Agreements}

Article 4(2) acknowledges the possibility that Protocol Parties may negotiate new international agreements that may 'relate' to the Protocol, including

49 Ibid., 204. Note that bilateral trade agreements could also address wTO law-related issues: see section 3 below.

50 See this commentary on Article 6.

$5^{1}$ Such as joint ventures: Nagoya Protocol Annex, 1(i). See this commentary on Article 5, section 6.

52 Jorge E. Viñuales, Foreign Investment and the Environment in International Law (Cambridge: Cambridge University Press, 2012), 205.

53 As investment tribunals are generally more reluctant to fully consider the implications of international environmental law for the disputes they are tasked to decide: Ibid., 215.

54 Ibid., 206.

55 As a highly specialized bioprospecting investor would find it difficult to argue that it was not (and could not have been) aware of relevant international environmental rules when arguing before an investment dispute settlement tribunal: ibid., 213. See discussion in this commentary on Article 6, Section 3.1. 
specialized ABS agreements but also other international instruments that only indirectly or partly concern ABS. But such possibility is conditioned upon ensuring that future international agreements 'are supportive of and do not run counter to the objectives of the Convention and of the Protocol'. The second (law-making) dimension of mutual supportiveness, therefore, comes into play when Article 4 refers to future international agreements. In light of the understanding of the principle of mutual supportiveness outlined above, it can be argued that Article 4(2) limits Parties' international law-making discretion by requiring that they exert good-faith efforts to negotiate and conclude new instruments with a view to clarifying the relationship with the Protocol and ensuring that the objectives of the $\mathrm{CBD}$ and the Protocol on achieving fair and equitable benefit-sharing among and within States ${ }^{56}$ are respected. That is, at the very least, Protocol Parties should seek to ensure not only that these objectives are not undermined, but also that their realization is contributed to, by future international agreements. ${ }^{57}$

Besides its relevance for future specialized ABS agreements (discussed below), the provision is of particular relevance for the ongoing negotiations under WIPO, also discussed below. It may also become particularly relevant for bilateral agreements to be concluded between a provider and user country to address either ABS issues in general or the implementation of the Protocol in particular.

Bilateral agreements may be particularly relevant in situations specifically foreseen by the Protocol, such as where transboundary cooperation may be necessary, ${ }^{58}$ but also focus on ${ }^{59}$ or deal with ABs in the context of broader bilateral trade and/or cooperation agreements. ${ }^{60}$ These agreements could certainly raise issues related to their mutual supportiveness with the Protocol, and Parties are therefore to exercise their negotiating discretion to ensure that

$56 \quad$ See this commentary on Article 1.

57 Indeed, Nagoya Protocol Article 4(2) explicitly points the negative and positive side 'supportive of and do not run counter to the objectives of the Convention and [the] Protocol'. See Pavoni, "Nagoya Protocol and wTo Law," op. cit., 207.

$5^{8}$ See this commentary on Article 11. Young, "An International Cooperation Perspective," op. cit., 496.

59 Ibid., 496-8. Young refers in particular to bilateral negotiations initiated by traditionally user countries, such as the us and Japan.

6o E.g., United States-Peru Trade Promotion Agreement (Washington, DC, 12 April 2006; in force 1 February 2009), Article 18(1) and "Us-Peru TPA, Understanding Regarding Biodiversity and Traditional Knowledge," us Government (2006), accessed 30 November 2013, <www.ustr.gov/sites/default/files/uploads/agreements/fta/peru/asset_upload_file 719_9535.pdf $>$; Free Trade Agreement between the EU and Its Member States, of the One Part, and Colombia and Peru, of the Other Part, [2012] oJ L354/3, Articles 272(2)-272(5). 
these agreements do not run counter to the CBD and Protocol objectives. This may prove particularly difficult in the case of free trade and/or investment agreements, whose lengthy text may include several non-ABs related clauses that may promote biodiversity-damaging activities. ${ }^{61}$ This also applies when bilateral agreements involve non-Parties to the Protocol, and can indeed provide a specific opportunity in which Parties can comply with their obligation to encourage non-Parties to adhere to the Protocol. ${ }^{62}$ In addition, international human rights law may also apply to these bilateral negotiations. Thus States are expected to ensure that they maintain adequate policy space to meet their international obligations relating to indigenous peoples, ${ }^{63}$ including when negotiating bilateral trade and investment agreements that may affect human rights applicable to ABS transactions. ${ }^{64}$

\subsection{WIPO Negotiations}

Established in 2001, the WIPO Intergovernmental Committee on Intellectual Property and Genetic Resources, Traditional Knowledge and Folklore (IGC) is a result of the influence of the СвD principles, as well as of developing countries' concerns regarding the consequences of patents over genetic resources and traditional knowledge, and injustices enshrined in the intellectual property system. ${ }^{65}$ The IGC has been undertaking text-based negotiations towards an international legal instrument or instruments to ensure the effective protection of genetic resources, traditional knowledge and traditional cultural expressions through intellectual property rights 'without prejudice to the work pursued in other fora. ${ }^{66}$ Such fora include in particular the TRIPS Council, other WIPO committees and bodies such as the Working Group on the Patent

61 Both the EU and the us have put in place environmental assessments of their bilateral trade negotiations with a view to identify possible negative impacts on the environment, but these and similar practices may require further refinement to better assess impacts on biodiversity and ABS-related issues. For a non-ABs related discussion, see Sikina Jinnah and Elisa Morgera, "Environmental Provisions in us and Eu Free Trade Agreements: A Preliminary Comparison and Research Agenda," Review of European, Comparative and International Environmental Law 22 (2013): 324.

62 See this commentary on Article 24.

63 See Introduction to this commentary, section 4.

64 UN General Assembly, "Human rights and transnational corporations and other business enterprises: note by the Secretary General" (6 August 2013) un Doc A/68/279 (advanced version), paragraph 55(e).

65 WIPO General Assembly, "Matters concerning the IGC," wo/GA/26/6.

66 In accordance with the IGC mandate as most recently renewed by the 2013 wIPO General Assembly. See Decision on agenda item 35 of wipo Assemblies 43rd (21st ordinary) session, 23 September-2 October 2013, "Matters concerning the IGC" Wo/GA/43/14. 
Cooperation Treaty, ${ }^{67}$ but also the CBD regarding the Nagoya Protocol negotiations and now the deliberations preparing for the Protocol's entry into force. ${ }^{68}$ While the WIPO negotiations go well beyond the scope of the Protocol, ${ }^{69}$ as they also concern traditional cultural expressions and are not linked to the conservation and sustainable use of biodiversity and the utilization of genetic resources, any future international instrument(s) on genetic resources and on traditional knowledge associated with genetic resources in the context of intellectual property will be implemented at a certain stage of the research and development chain (i.e. commercialization or pre-commercialization), that is also regulated by the Nagoya Protocol.

At the time of writing, the negotiations under WIPO are still ongoing. ${ }^{70}$ The Protocol's negotiating history appears to include the WIPO IGC negotiations among the 'ongoing work' expected to be kept under review under Article 4(3). ${ }^{71}$ Should the WIPO negotiations be completed successfully, the resulting international instrument(s) will be 'relevant' to the Protocol pursuant to Article 4(3). This would be particularly true with regard to the intersection between ABS and intellectual property rights, especially in view of the fact that the Nagoya Protocol shies away from imposing IPR-related benefit-sharing 72 or a requirement of mandatory disclosure of the origin or source of genetic resources used in a product at the time of filing a patent application ${ }^{73}$ - issues which are currently under negotiation in the WIPO IGC framework. The scope and

67 See for instance the Swiss proposal for amending the wipo International Patent Cooperation Union Working Group on reform of the Patent Cooperation Treaty, "Declaration of the source of genetic resources and traditional knowledge in patent applications. Proposals submitted by Switzerland," (7 March 2007) wiPo Doc PCT/R/WG/9/5.

68 See for instance inclusion of references to the Nagoya Protocol in the WIPO IGC draft negotiating texts regarding the definitions, disclosure requirement and defensive protection of traditional knowledge: WIPO General Assembly, "Matters concerning the IGC," wo/GA/43/14, Annex A, 2.

69 See Introduction to this commentary, section 3. See also свD Working Group on ABs, "Study on the relationship between an international regime on access and benefit-sharing and other international instruments and forums that govern the use of genetic resources. The World Trade Organization (wTO); the World Intellectual Property Organization (WIPO); and the International Union for the Protection of New Varieties of Plants (UPOV)" (3 March 2009) Un Doc UneP/CbD/WG-ABs/7/INF/3/PART2.

70 See wipo General Assembly, "Matters concerning the IGC," Wo/GA/43/14.

71 свD Decision X/1, paragraph 6.

72 Pavoni, "The Nagoya Protocol and wTo," op. cit., 202.

73 Which had been considered through a combination of provisions during the negotiations: Cali Draft, draft article 13(1)(a), 13(1)(a)(iv) and 13(3) - see comments by Pavoni, “Nagoya Protocol and wTo Law," op. cit., 203-204, and this commentary on Article 17. 
specific provisions of a future WIPO instrument may thus result in strengthening (or weakening, depending on the outcome of the negotiations) the linkages between the two instruments, as well as the Protocol's objective. Overall, the effect of Article 4(2) and 4(4) for the Parties that are involved in the WIPO negotiations is that they 'are bound not to develop and implement agreements that would be at variance with the СвD and Protocol objectives, ${ }^{74}$ notably achieving fair and equitable benefit-sharing between and within States, with a view to contributing to biodiversity conservation and sustainable use.

\section{Relationship with Specialized ABS Instruments}

As indicated above, Article 4(2) specifically foresees the conclusion of future specialized ABS agreements. The provision thereby implies that СвD Parties expect that more specific international instruments will be developed to deal with certain sectors of genetic resources. ${ }^{75}$ It thus clarifies that the Protocol is not expected to be a comprehensive instrument, but rather applies by default where more specific international agreements have not been adopted to ensure the implementation of the ABS provisions of the Convention. Interpreting Article 4(2) in the light of the principle of mutual supportiveness, ${ }^{76}$ Parties are subject to an international obligation to negotiate such specialized ABs instruments in a manner that proactively supports the realization of the objectives of the Convention and the Protocol, or at least avoids running counter to these objectives.

The adoption of instruments in compliance with Article 4(2) is then characterized by Article 4(4) as a condition for specialized ABs instruments to prevail as lex specialis over the Protocol for those Parties that are Party to both instruments, as well as in respect of the specific genetic resources covered by and for the purpose of the specialized instrument. Thus, if a specialized ABS

\footnotetext{
74 Pavoni, “The Nagoya Protocol and wTo," op. cit., 207.

75 Свр Working Group on Aвs, "Access and benefit-sharing arrangements existing in specific sectors" (11 January 2008) UN Doc UNEP/CBD/WG-ABs/6/INF/4/REvl.

76 Laurence Boisson de Chazournes and Makane M. Mbengue, "A Propos du Principe Soutien Mutuel: les Relations entre le Protocol de Cartagena et les Accords de l'omc," Revue Générale de Droit International Public 4 (2007): 829; Laurence Boisson de Chazournes and Makane M. Mbengue, "A 'Footnote as a Principle.' Mutual Supportiveness and Its Relevance in an Era of Fragmentation," in Coexistence, Cooperation and Solidarity: Liber Amicorum Rüdiger Wolfrum, ed. Holger P. Hestermeyer et al. (Leiden: Martinus Nijhoff, 2011), 1615; and Pavoni, "Mutual Supportiveness," op. cit.
} 
agreement is deemed inconsistent with the objectives of the CBD and the Protocol, Parties should not apply it. ${ }^{77}$

As to existing specialized ABS agreements that would come into play in implementing Article 4(4), the Protocol preamble points to the International Treaty on Plant Genetic Resources for Food and Agriculture, ${ }^{78}$ and the wHO International Health Regulations (2005), ${ }^{79}$ suggesting that, as of 2010, these meet the criteria of Article 4(4). As to the latter, it should be emphasized that shortly after the conclusion of the negotiations of the Protocol, the wHO completed the negotiations of a Pandemic Influenza Preparedness Framework (PIP Framework), which can also be seen as a specialized ABs instrument. ${ }^{80} \mathrm{In}$ addition, the negotiating history of Article 4 points to possible future specialized $A B S$ instruments, ${ }^{81}$ such as a new international instrument or provisions on marine genetic resources in areas beyond national jurisdiction; and possible new sectoral instruments to be developed under the FAO Commission on Genetic Resources for Food and Agriculture (CGRFA). The following subsections will discuss each of the existing and potential future specialized ABS agreements in turn.

\subsection{Genetic Resources Covered by the ITPGRFA}

The preamble to the Protocol acknowledges the 'fundamental role' of the ITPGRFA in relation to the interdependence of all countries with regard to plant genetic resources for food and agriculture, their special nature, and

77 Chiarolla, Louafi and Schloen, "Analysis of the Relationship," op. cit., 102.

78 Nagoya Protocol 16th and 19th preambular recitals.

79 Nagoya Protocol 17th preambular recital. Revision of the wHo International Health Regulations (Geneva, 23 May 2005, in force 15 June 2007).

8o Note that the Nagoya Protocol refers to specialized ABs 'agreements' in Article 4(2), but 'instruments' in Article 4(4). The who Pandemic Influenza Preparedness Framework for the sharing of influenza viruses and access to vaccines and other benefits (effective 24 May 2011) wHо Dос WHA64.5, is a soft-law instrument and not a legally-binding treaty, although arguably its effects on the conduct of wHo Member States go well beyond those traditionally ascribed to soft-law instruments, as discussed below (see section 4.2 below).

81 свD COP, "Report of the Ad Hoc Open-ended Working Group on Access and BenefitSharing on the work of its sixth meeting" (31 January 2008) Un Doc UNEP/CBD/COP/9/6, 14-16; and Montreal I Draft draft article 3(c), which reads: 'Genetic resources [contained in Annex I of the International Treaty on Plant Genetic Resources for Food and Agriculture provided they are used for the purposes of the International Treaty on Plant Genetic Resources for Food and Agriculture][under the Multilateral System of the International Treaty on Plant Genetic Resources for Food and Agriculture, both current and as may be amended by the Governing Body of the International Treaty on Plant Genetic Resources for Food and Agriculture].' (brackets in the original). 
importance for achieving food security worldwide and sustainable development of agriculture in the context of poverty alleviation and climate change. ${ }^{82}$ The preamble further recalls the Multilateral System of ABs established under the ITPGRFA 'in harmony with the Convention. ${ }^{\prime 83}$ For its part, the ITPGRFA was specifically negotiated to ensure harmony with the $\mathrm{CBD},{ }^{84}$ and its stated objective refers to 'harmony with the СвD and its objectives.' ${ }^{85}$ It can thus be asserted that the ITPGRFA is an existing specialized international ABS instrument 'that has the same legal status of, and is consistent with, the СвD and its Nagoya Protocol. ${ }^{86}$ Accordingly, Article 4(4) can be interpreted as a legal presumption of compatibility between the International Treaty, the СвD and the Nagoya Protocol, that may not be rebutted. ${ }^{87}$

In view of the distinctive features of agricultural biodiversity, ${ }^{88}$ the International Treaty takes a markedly different approach to ABS than the Protocol,

$82 \quad$ Nagoya Protocol 16th preambular recital.

83 Nagoya Protocol 19th preambular recital.

84 FAO Conference Resolution 7/93 "Revision of the international undertaking on plant genetic resources," (1993) requested intergovernmental negotiations on: the revision of the International Undertaking on Plant Genetic Resources for Food and Agriculture to be in harmony with the СвD; the issue of access, on mutually agreed terms, to plant genetic resources, including ex situ collections not addressed by the СвD; and the realization of farmers' rights.

85 ITPGRFA Article 1 reads: ' 1 The objectives of this Treaty are the conservation and sustainable use of plant genetic resources for food and agriculture and the fair and equitable sharing of the benefits arising out of their use, in harmony with the Convention on Biological Diversity, for sustainable agriculture and food security. 2 These objectives will be attained by closely linking this Treaty to the Food and Agriculture Organization of the United Nations and to the Convention on Biological Diversity.'

86 Chiarolla, Louafi and Schloen, "Analysis of the Relationship," op. cit., 105. See also СвD Working Group on ABS, "Study on the relationship between an international regime on access and benefit-sharing and other international instruments and forums that govern the use of genetic resources. The International Treaty on Plant Genetic Resources for Food and Agriculture and the Commission on Genetic Resources for Food and Agriculture of the Food and Agriculture Organization of the United Nations" (3 March 2009) UN DOC UNEP/CBD/WG-ABS/7/INF/3/Part.1.

87 Ibid., 103. Note, however, that the ITPGRFA will have to be interpreted and applied in a mutually supportive manner with regard to the Nagoya Protocol provisions on indigenous and local communities' PIC and benefit-sharing concerning traditional knowledge and genetic resources held by them, which may pose specific challenges as the International Treaty provisions on farmers' rights are markedly different in approach and in level of detail than the relevant provisions of the Nagoya Protocol. For a discussion, Chiarolla, Louafi and Schloen, "Analysis of the Relationship," op. cit., 110-114.

88 See also this commentary on Article 8, section 4. 
namely it is built on a multilateral - rather than prevalently bilateral approach. ${ }^{89}$ The rationale is to some degree described in the preamble to the Treaty. First, agriculture in all countries depends largely on plant genetic resources that have originated elsewhere. Continued and unrestricted access to plant genetic resources, therefore, is indispensable for the crop improvements that are necessary for sustainable agriculture and food security, in the face of genetic erosion, environmental changes, and future human needs. Furthermore, given the millennia of agricultural history, the geographical origins of plant genetic resources are often impossible to locate, and thus, identification of the country of origin is very difficult. Genebanks all over the world now have collections of all major crops, making the search for genetic resources in situ unnecessary. ${ }^{90}$

Against this background, the International Treaty has created a multilateral system aimed at facilitating access to, and exchange of, a specified list of crops ${ }^{91}$ considered vital for food security and agricultural research, and at institutionalizing the sharing of benefits arising from the utilization of these resources. ${ }^{92}$ Benefits include non-monetary ones, such as exchange of information, access to and transfer of technology, capacity building and facilitated access to crops, recognized as a benefit in itself. Sharing of benefits arising from commercialization is done through standard payments by the users of material accessed from the multilateral system, according to the provisions of the standard Material Transfer Agreement (smTA), adopted by the ITPGRFA Governing Body. ${ }^{93}$

89 UN General Assembly, "Interim report of the Special Rapporteur on the right to food: Seed policies and the right to food: enhancing agrobiodiversity and encouraging innovation" (23 July 2009) un Doc A/64/170, paragraphs 10 and 21-22. See also Michael Halewood et al., "Implementing 'Mutually Supportive' Access and Benefit Sharing Mechanisms under the Plant Treaty, Convention on Biological Diversity, and Nagoya Protocol," Law Environment and Development Journal 9 (2013): 68, 71.

90 See David H. Cooper, "The International Treaty on Plant Genetic Resources for Food and Agriculture," Review of European Community and International Environmental Law 11 (2002): 1, 4; Gerald K. Moore and Witold Tymowski, Explanatory Guide to the International Treaty on Plant Genetic Resources for Food and Agriculture (Gland: IUCN, 2005), 2-6.

91 ITPGRFA Annex I.

92 ITPGRFA Articles 10-13. See Tsioumani, "International Treaty on Plant Genetic Resources for Food and Agriculture," op. cit., 128.

93 ITPGRFA Governing Body Resolution 2/2006, "On the Standard Material Transfer Agreement” (16 June 2006). Users of material accessed from the Multilateral System must choose between two mandatory monetary benefit-sharing options: a default benefitsharing scheme, according to which the recipient will pay 1.1 percent of gross sales to the Treaty's benefit-sharing fund in case of commercialization of new products incorporating material accessed from the MLS and if its availability to others is restricted; and 
Such payments, together with voluntary donations, are directed to the Treaty's benefit-sharing fund, which allocates funds under the direction of the ITPGRFA Governing Body, to particular activities designed to support farmers in developing countries in conserving crop diversity in their fields, and assist farmers and breeders globally in adapting crops to changing needs and demands. The benefit-sharing fund is thus mandated to prioritize projects that support not only the conservation and sustainable use of agricultural biodiversity, but also the livelihoods of farmers and rural communities. ${ }^{94}$

In this connection, the Protocol negotiators debated whether to specifically exclude the ITPGRFA Annex I resources from the scope of the Protocol, ${ }^{95}$ but eventually opted for a more general provision in the form of Article 4. As a specialized ABS agreement consistent with the objectives of the СвD and the Protocol as per Article 4(4), the provisions of the Treaty 'will prevail over those of the Protocol with respect to [plant genetic resources for food and agriculture] that are covered by the MLS and that are accessed for the purpose of research, breeding and training for food and agriculture. ${ }^{96}$ In cases where the resources under the Treaty are used for other purposes (such as for chemical, pharmaceutical and/or non-food and non-feed industrial uses), the Nagoya Protocol will apply. ${ }^{97}$ With regard to agricultural research, however, and on the basis of the recognition of the specific features of agricultural biodiversity and the role and scope of the International Treaty in that regard, the Nagoya Protocol arguably does not preclude making available non-Annex I plant genetic resources under the same conditions provided for under the Multilateral

an alternative formula whereby recipients pay 0.5 percent of gross sales on all PGRFA products of the species they accessed from the MLS, regardless of whether the products incorporate the material accessed and regardless of whether or not the new products are available without restriction. See "Standard Material Transfer Agreement," ITPGRFA (16 June 2006), accessed 30 November 2013, <ftp://ftp.fao.org/ag/agp/planttreaty/agree ments/smta/SMTAe.pdf> (smTA) Articles 6(7) and 6(11).

See Tvedt and Young, Beyond Access, op. cit., 124.

95 Montreal II Draft, draft article 3(c).

96 Chiarolla, Louafi and Schloen, "Analysis of the Relationship," op. cit., 103. See also Michael Halewood, Isabel Lopez Noriega and Sélim Louafi, "The Global Crop Commons and Access and Benefit-Sharing Laws: Examining the Limits of International Policy Support for the Collective Pooling and Management of Plant Genetic Resources," in Crop Genetic Resources as a Global Commons. Challenges in International Law and Governance, ed. Michael Halewood, Isabel Lopez Noriega and Sélim Louafi (London: Routledge, 2013), $1,7$.

97 Chiarolla, Louafi and Schloen, “Analysis of the Relationship," op. cit., 109. 
System (MLS), i.e. using the SMTA, ${ }^{98}$ as long as this is specifically decided upon by the ITPGRFA Governing Body, which would take into consideration also the Nagoya Protocol's provisions and requirements. This may be the case of plant genetic resources covered by the agreements between the international agricultural research centers of the Consultantive Group on International Agricultural Research (CGIAR Consortium) and the ITPG RFA Governing Body. ${ }^{99}$ This may also be the case of materials voluntarily made available by ITPGRFA Parties under the conditions of the SMTA, ${ }^{100}$ as long as they are the countries of origin or have acquired the material in accordance with the СвD. Therefore, on the basis of a combined reading of Articles 4 and 8, the Protocol seems to allow for differentiated treatment of plant genetic resources for food and agriculture purposes both at the international level, using the multilateral ABS framework of the ITPGRFA, and at the national level, on the basis of national legislation. ${ }^{101}$

\subsection{Genetic Resources with Pathogenic Properties}

Some genetic resources have pathogenic properties, i.e. they may cause disease to other organisms. The same genetic resources are used for medical research

98 Ibid., 106-9. See also свд Working Group on ABs, "Study on the relationship with the ITPGRFA," Un Doc UNEP/CBD/ABS/7/INF.3/Part I, paragraphs 2.2.2-3 and 3.3.15.

99

The issue of the use of the smta for exchanges of non-Annex I plant genetic resources for food and agriculture collected before the Treaty's entry into force (ITPGRFA Article 15(1)(b)) was addressed at the second session of the ITPGRFA Governing Body, which endorsed including an interpretative footnote or series of footnotes to relevant provisions of the SMTA, to indicate that the provisions should not be interpreted as precluding the use of the SMTA for transfers of non-Annex I material collected before the entry into force of the Treaty. See ITPGRFA, "Report of the Second Session of the Governing Body of the ITPGRFA" (2007) FAO Doc IT/GB-2/07/Report, 11; and ItPGRFA Secretariat "Consideration of the Material Transfer Agreement to be used by international agricultural research centres for plant genetic resources for food and agriculture not included in Annex 1 of the Treaty" (2007) FAO Doc IT/GB-2/07/13. Accordingly, the international agricultural research centres have been using the SMTA, including interpretative footnotes, for transfer of non-Annex I material. The Governing Body reviewed this use of the SMTA at all its subsequent sessions, without amending its decision. At its fourth session, it noted the continued successful use of the SмтA by the centres, and at the latest fifth session, it commended the centres for their continued use of the sMTA for the transfer of non-Annex I plant genetic resources. See ITPGRFA, "Report of the Fourth Session of the Governing Body to the ITPGRFA" (2011) FAo Doc IT/G B-4/11/Report, Appendix A, 28; and "Report of the Fifth Session of the Governing Body to the ITPGrfa (2013) FAO Doc IT/G B-5/13/Report, Appendix A, 5.

100 Chiarolla, Louafi and Schloen, "Analysis of the Relationship," op. cit., 106-7

101 See Nagoya Protocol Article 8(c) and this commentary on Article 8, section 4. 
purposes and production of vaccines. Pathogens were not considered as an issue in the negotiation of the СвD, or later by СвD Parties when deliberating on the implementation of the Convention. The issue surfaced for the first time in the negotiation of the Nagoya Protocol in 2009. ${ }^{102}$ This followed developments in the context of WHO negotiations to increase equitable access to vaccines for highly pathogenic avian influenza A and pandemic influenza A. ${ }^{103}$ Concerns that developing country populations may not have access to influenza vaccines due to insufficient global production, and the lack of any mechanism to ensure equitable access to other benefits from research on influenza viruses, prompted Indonesia to refuse to share its $\mathrm{H} 5 \mathrm{~N} 1$ virus samples with the WHO, on the basis of СвD Article 15(7). ${ }^{104}$ Concretely, Indonesia sought preferential access to vaccines and transfer of related patents developed from its virus sample to enable its own pharmaceutical companies to produce vaccines at low cost. ${ }^{105}$ This move was explicitly supported by most developing countries

102 Nagoya Draft, draft article 3(f). See свр Working Group on ABs, "Report of the Seventh Meeting” (5 May 2009) un Doc UnEP/CbD/WG-ABs/7/8, paragraphs 58, 115-116. See also ENB, "Summary of the Seventh Meeting of the Working Group on Access and BenefitSharing of the Convention on Biological Diversity: 2-8 April 2009," Vol 9 No 465, 10 April 2009.

103 David P. Fidler, "Negotiating Equitable Access to Influenza Vaccines: Global Health Diplomacy and the Controversies Surrounding Avian Influenza H5N1 and Pandemic Influenza H1Nl, PLoS Medicine 7 (2010): 1.

104 Indonesia's refusal to share its virus samples was based on СвD principles: it was argued that it had the right to refuse to share the samples because it controlled access on samples collected in its territory. Other Parties could not use them without their prior informed consent, and their use should result in benefits for Indonesia. See Morgera and Tsioumani, "Evolution of Benefit-Sharing," op. cit., 170; David P. Fidler, "Influenza Virus Samples, International and Global Health Diplomacy," Emerging Infectious Diseases 14 (2008): 88, cited in Regine Andersen et al., International Agreements and Processes Affecting an International Regime on Access and Benefit Sharing Under the Convention on Biological Diversity: Implications for Its Scope and Possibilities of a Sectoral Approach, Fridtjof Nansen Institute Report No. 3/2010 (Lysaker: Fridtjof Nansen Institute, 2010), 40.

105 See Marie Wilke, "A Healthy Look," op. cit., 123. For an overview of the wHo negotiations see also South Centre and Centre for International Environmental Law, Intellectual Property Quarterly Update, Third Quarter (South Centre and Centre for International Environmental Law, 2009), accessed 30 November 2013, <www.ciel.org/Publications/ IP_Update_3Q09.pdf>, 10; wHo Secretariat, "Pandemic Influenza Preparedness: Sharing of Influenza Viruses and Access to Vaccines and Other Benefits" (27 November 2008) шно Dос вв124/4; and wно Secretariat, "Pandemic Influenza Preparedness: Sharing of Influenza Viruses and Access to Vaccines and Other Benefits: Outcome of the Process to Finalize Remaining Elements under the Pandemic Influenza Preparedness Framework for 
and initiated a fully-fledged negotiation in the wHO to reform the system for the rapid sharing of virus samples and access to vaccines. This resulted in the adoption of the PIP Framework only months after adoption of the Nagoya Protocol.

During the Protocol negotiations, the issue was addressed under deliberations on scope, when developed countries sought an explicit exclusion of genetic resources with pathogenic properties from the Protocol's scope, and developing countries sought to explicitly include viruses and other pathogenic material within the Protocol's scope. ${ }^{106}$ Negotiators finally decided against a specific inclusion or exclusion of pathogens in the Protocol, in favor of the general provisions under Articles 3-4 and the special considerations under Article 8(b). The wHo framework and the importance of ensuring access to human pathogens for public health purposes are also reflected in the preamble. ${ }^{107}$

While it is acknowledged that pathogens used to develop vaccines and medicines are economic resources covered by the commercial dimension of $\mathrm{ABS}$, strict ABS rules based on the principle of national sovereignty in the case of pathogens are generally not regarded as conducive to facilitating timely sharing of virus samples required to improve global health governance. ${ }^{108}$ In recognition of this, the PIP Framework is considered 'the first ABS mechanism in the area of public health. ${ }^{109}$ Its scope is, however, limited: the PIP Framework applies only to influenza viruses with pandemic potential. All other pathogens remain under the scope of the Protocol. ${ }^{110}$ This is in particular the case of seasonal influenza viruses, and other non-influenza pathogens or biological substances that may be contained in clinical specimens shared through the Framework, which, even when accidentally shared, remain outside the scope of the wHo Global Influenza Surveillance and Response System, and thus within the scope of the Nagoya Protocol.111

In addition, it has been argued that, as the Framework was adopted through a formally non-binding WHO Assembly resolution, it only functions as a

the Sharing of Influenza Viruses and Access to Vaccines and other Benefits" (10 December 2009) Wно Doc Eв126/4.

106 See enв 9/465, "Summary of the Seventh Meeting of the Working Group on ABs." For a broader discussion on the negotiations on scope, see this commentary on Article 3.

107 Nagoya Protocol 17th preambular recital.

108 Andersen et al., International Agreements and Processes, op. cit., 37.

109 Wilke, "A Healthy Look," op. cit., 137. For a discussion of the framework, see ibid., 138.

110 Ibid., 126.

111 PIP Framework Article 3(2). See Wilke, "A Healthy Look," op. cit., 146; and this commentary on Article 8, section 3. 
specialized ABS agreement for transfer of influenza viruses that are covered by the Framework's binding contractual clauses that are stipulated in standard material transfer agreements (WHO-SMTAs). ${ }^{112}$ The WHO-SMTAs, which regulate the exchange of samples and introduce binding benefit-sharing obligations, automatically apply to any actor that makes use of the WHO system, whether it is a submitting National Influenza Centre, a wHo laboratory or an outside institution that seeks to receive processes material for commercial or non-commercial utilization. Thus, while the Framework agreement is nonbinding for Member States, use of the system is governed by binding wH OSMTAs in the form of contract clauses. WHO-SMTAl applies automatically to institutions within the Global Influenza Surveillance and Response System (i.e., the National Influenza Centres and the wHo laboratories) in accordance with standard terms of reference attached to the Framework. ${ }^{113}$ WHO-SMTA2 applies to recipients of material outside the system and needs to be negotiated by wHO and any outside institution requesting material, prior to the transfer. ${ }^{114}$

The discussion above indicates that the PIP Framework establishes a specialized ABs framework covering influenza viruses with pandemic potential, that combines a multilateral system and a bilateral one, which however is governed internationally. The PIP Framework negotiations were finalized following conclusion of the Nagoya Protocol negotiations and were informed by those. ${ }^{115}$ In addition, the Framework's objective is to establish a fair, transparent, equitable, efficient, effective system for, on an equal footing, the sharing of viruses, and access to vaccines and sharing of other benefits. Therefore, in line with the Nagoya Protocol, the PIP Framework seeks to ensure both access and benefit-sharing, and this objective is strengthened through the provisions of the Framework and the WHO-SMTAs. It can thus be concluded that the PIP Framework is consistent with, and does not run counter to the objectives of the Convention and the Nagoya Protocol, and can therefore be considered a specialized instrument in the context of Article 4(4). ${ }^{116}$

112 Included in an Annex to the Framework. Wilke, "A Healthy Look," op. cit., 126.

113 PIP Framework Annexes 4-8. Note that SMTAl includes no benefit-sharing obligations but a statement prohibiting the granting of intellectual property rights on the material. See Wilke, "A Healthy Look," op. cit., 140.

114 PIP Framework Annex 2, Article 4(4). Note that SMTA2 allows for intellectual property rights, but combines them with at least two different benefit-sharing activities. See Wilke, "A Healthy Look," op. cit., 140.

115 See Wilke, "A Healthy Look," op. cit., 146.

116 Ibid., 144. With regard to the Св D objectives of biodiversity conservation and sustainable use, Wilke further argues that the fight against highly aggressive zoonotic viruses supports these objectives, along with public health efforts. 


\subsection{Marine Genetic Resources in Areas Beyond National Jurisdiction}

A specialized ABS regime concerning marine genetic resources in areas beyond national jurisdiction may emerge from ongoing discussions ${ }^{117}$ that have been entertained since 2006 under the UN General Assembly's Ad Hoc Open-ended Informal Working Group to study issues relating to the conservation and sustainable use of marine biological diversity beyond areas of national jurisdiction. ${ }^{118}$ Such an instrument could cover ABs in relation to genetic resources from the seabed beyond national jurisdiction (the Area), and genetic resources from the water column beyond national jurisdiction (the high seas). ${ }^{119}$

At the time of writing, these discussions, while not having yet reached the stage of formal intergovernmental negotiations, have identified a package of issues that could be addressed in a new implementing agreement under the UN Convention on the Law of the Sea, namely: marine genetic resources, including questions on benefits-sharing; but also measures such as area-based management tools, including marine protected areas and environmental impact assessments; capacity building and the transfer of marine technology. ${ }^{120}$ It is

117 UN General Assembly, "Oceans and the Law of the Sea," (17 November 2004) Un Doc A/ $\operatorname{RES} / 59 / 24$ establishing the original mandate of the Working Group. See generally, Tullio Scovazzi, "Bioprospecting on the Deep Seabed: A Legal Gap Requiring to Be Filled," in Francioni and Scovazzi, Biotechnology and International Law, op. cit., 81; Lyle Glowka, "Evolving Perspectives on the International Seabed Area's Genetic Resources Fifteen Years after the 'Deepest of Ironies'," in Law, Technology and Science for Oceans in Globalisation, ed. Davor Vidas (Leiden: Martinus Nijhoff, 2010) 397; Tullio Scovazzi, "The Exploitation of Genetic Resources in Areas Beyond National Jurisdiction," in Confronting Ecological and Economic Collapse: Ecological Integrity for Law, Policy and Human Rights, ed. Laura Westra, Prue Taylor and Agnès Michelot (London: Routledge, 2013), 47; Louise A. de la Fayette, "A New Regime for the Conservation and Sustainable Use of Marine Biodiversity and Genetic Resources Beyond the Limits of National Jurisdiction," The International Journal of Marine and Coastal Law 24 (2009): 221; Thomas Greiber, "Common Pools for Marine Genetic Resources: A Possible Instrument for a Future Multilateral Agreement Addressing Marine Biodiversity in Areas Beyond National Jurisdiction," in Kamau and Winter, Common Pools of Genetic Resources Equity and Innovation in International Biodiversity Law, op. cit., 399; Morten W. Tvedt and Ane E. Jørem, "Bioprospecting in the High Seas: Regulatory Options for Benefit Sharing," The Journal of World Intellectual Property 16 (2013): 150; and Bevis Fedder, Marine Genetic Resources, Access and BenefitSharing (London: Routledge, 2013).

118 For a discussion of the possible interactions between the Working Group and the Nagoya Protocol, see Salpin, "Law of the Sea," op. cit., 179-182.

119 Ibid., 174.

120 Un General Assembly, "Oceans and the Law of the Sea," (5 April 2012) Un Doc A/ RES/66/231, paragraph 14. 
expected that the Working Group will reach a conclusion on the feasibility, scope and parameters of a new international instrument on marine biodiversity under UNCLOS towards the end of 2015, with a view to preparing for a decision by the General Assembly before the end of its sixty-ninth session. ${ }^{121}$

Should a formal negotiating process be launched under the General Assembly, Parties to the Protocol will be bound by Article 4(2) to ensure that specialized ABS arrangements in the context of a new implementing agreement under UNCLOS do not run counter to the objectives of the Convention and the Protocol in achieving fair and equitable benefit-sharing among and within States, and biodiversity conservation and sustainable use. Even from the viewpoint of those arguing that areas beyond natural jurisdiction are outside the scope of the Protocol, ${ }^{122}$ a similar obligation would still exist on the basis of a general principle of mutual supportiveness. ${ }^{123}$

In all events, the concepts of 'biodiversity' and 'genetic resource' are not mentioned in UNCLOS, therefore a certain reliance on the CBD and the Nagoya Protocol will be inevitable in the context of negotiations under the authority of the UN General Assembly. There is certainly scope for a mutually supportive interpretation of the law of the sea and the international biodiversity regime that can build on the open-textured environmental provisions of UNCLOS and take advantage of the several textual hooks for an evolving, biodiversitycognizant interpretation. ${ }^{124}$ On the other hand, however, the fundamental difference between the two sets of international rules is that while the СвD and the Nagoya Protocol are mainly premised on genetic resources within national jurisdiction and appear to favor a bilateral approach to ABS, a future specialized ABS agreement on marine genetic resources in areas beyond national jurisdiction ${ }^{125}$ will inevitably deal with genetic resources that are open to appropriation by any State in the high seas and possibly subject to the common heritage regime of mankind if found in the Area. ${ }^{126}$ It therefore appears

121 UN General Assembly, "Oceans and the Law of the Sea," (9 December 2013) Un Doc A/ RES/68/70, paragraphs 197-198.

122 See this commentary on Article 3, section 3.2.

123 See generally Pavoni, "Mutual Supportiveness," op. cit.

124 Boyle and Chinkin, Making of International Law, op. cit., 256-259; and Birnie, Boyle and Redgwell, International Law and the Environment, op. cit., 746-751.

125 Salpin, "Law of the Sea," op. cit., 174.

126 States participating in the UN General Assembly's Working Group have put forward two different legal interpretations about the legal status of marine genetic resources in the Area: they may be subject to the general regime of the freedom of the high seas, as a residual regime (UNCLOS Article 86) because the common heritage regime applicable to the Area only concerns mineral resources in light of UNCLOS Article 133(a); or they may 
more likely that a multilateral system of benefit-sharing may be conceived in that context. ${ }^{127}$

\subsection{CGRFA}

Since 2007 the FAO Commission on Genetic Resources for Food and Agriculture has reviewed arrangements and policies on uses and exchanges of genetic resources in different subsectors of food and agriculture. These subsectors include animal, aquatic, forest and microbial genetic resources. ${ }^{128}$ Following the adoption of the Nagoya Protocol, the Commission engaged in assessing

be subject to the common heritage regime under the understanding that the Area and its resources include biological resources, as part of customary international law. See ENB, "Summary of the Sixth Meeting of the Working Group on Marine Biodiversity beyond Areas of National Jurisdiction: 19-23 August 2013," unnumbered, accessed 30 November 2013, <www.iisd.ca/oceans/marinebiodiv6/brief/brief_marinebiodiv6e.html>) or a contextual interpretation of UNCLOS according to which the relevant rights and obligations are not determined by the nature (mineral or genetic) of the resource, but by the relevant maritime area in which resources are found: see Elisa Morgera, "Impressions on the UN General Assembly Working Group on Marine Biodiversity," Environmental Policy and Law 40 (2010): 67.

127 The EU has in effect suggested drawing inspiration from the ITPGRFA approach in that context: ENB, "Summary of the Working Group on Marine Biodiversity Beyond Areas of National Jurisdiction: 1-5 February 2010," unnumbered, accessed 30 November 2013, $<$ www.iisd.ca/oceans/marinebiodiv3/brief/brief_marinebiodiv3.pdf>, 5; and ENB, "Summary of the Second Meeting of the Working Group on Marine Biodiversity Beyond Areas of National Jurisdiction: 28 April-2 May 2008," Vol. 25 No. 49, 5 May 2008, 7.

128 Chiarolla, Louafi and Schloen, "Analysis of the Relationship," op. cit., 116. See FAO, The Use and Exchange of Animal Genetic Resources for Food and Agriculture (FAO, 2009), accessed 30 November 2013, <ftp://ftp.fao.org/docrep/fao/meeting/017/ak222e.pdf>; FAO, The Use and Exchange of Aquatic Genetic Resources for Food and Agriculture (FAO, 2009), ftp://ftp.fao.org/docrep/fao/meeting/017/ak527e.pdf.; FAO, The Use and Exchange of Forest Genetic Resources for Food and Agriculture (FAO, 2009), accessed 30 November 2013, <ftp://ftp.fao.org/docrep/fao/meeting/017/ak565e.pdf>; and FAO, The Use and Exchange of Microbial Genetic Resources for Food and Agriculture (FAO, 2009), accessed 30 November 2013, <ftp://ftp.fao.org/docrep/fao/meeting/017/ak566e.pdf>. See also, preNagoya Protocol: СвD Working Group on ABs, "The use and exchange of animal genetic resources for food and agriculture - Submission by the Food and Agriculture Organization of the United Nations (FAO)" (9 March 2010) Un Doc UneP/CBD/WG-Abs/9/InF/10; "The use and exchange of forest genetic resources for food and agriculture - Submission by the Food and Agriculture Organization of the United Nations (FAO)" (9 March 2010) UN Doc $\mathrm{UNEP} / \mathrm{CBD} / \mathrm{WG}-\mathrm{ABS} / 9 / \mathrm{INF} / 11$; and "The use and exchange of aquatic genetic resources for food and agriculture - Submission by the Food and Agriculture Organization of the United Nations (FAO)" (9 March 2010) Un Doc UNEP/CBD/WG-ABS/9/INF/12. 
whether distinctive features of the different sectors and sub-sectors of genetic resources for food and agriculture may require distinctive solution and in particular specific ABS modalities 'taking into account the full range of options, including those presented in the Nagoya Protocol.'129

In 2013, the Commission considered it premature to negotiate an international agreement or agreements on ABs for genetic resources for food and agriculture. It rather proposed to engage in further work towards the development of a voluntary tool to facilitate domestic implementation of ABs for different sub-sectors of genetic resources for food and agriculture, taking into account relevant international instruments on ABS, and considering stakeholder groups' voluntary codes of conduct, guidelines and best practices in relation to ABs for all sub-sectors of genetic resources for food and agriculture. ${ }^{130}$ So, while this work does not yet seem relevant for the purposes of the Protocol Article 4(4), it will certainly be relevant for the review of ongoing intergovernmental work and practices under Article 4(3). Depending on its focus (i.e., if addressed to stakeholder groups directly), it could also potentially feed into the review of codes of conduct and other voluntary instruments by the Protocol's governing body.131

129 CGRFA, "Report of the thirteenth regular session of the Commission on Genetic Resources for Food and Agriculture" (18-22 July 2011) FAO DOC CGRFA-13/11/Report, paragraph 60 and Appendix $\mathrm{D}(1)$.

130 CGRFA, "Report of the fourteenth regular session of the Commission on Genetic Resources for Food and Agriculture" (15-19 April 2013) FAO DOC CGRFA-14/13/DR, paragraph $40(\mathrm{xv})$.

131 Nagoya Protocol Article 20(2). See also this commentary on Article 20, section 3. 